\title{
DZIAŁALNOŚĆ PROJEKTOWA A STRATEGICZNE CELE ROZWOJU MIASTA, NA PRZYKŁADZIE ŁUCKA NA UKRAINIE
}

\section{Abstract \\ Project Activities and Strategic Development of the City, for Example, Lutsk in Ukraine}

The article describes the impact of the implementation of projects in the units of local self-government on efficiency in the development of the city in accordance with the planned strategic goals. Considerations also include the impact of experience of local authorities in Poland on the management of projects in the units of local self-government in Ukraine. This paper presents the views of the residents of the city of Lutsk in Ukraine to assess the effectiveness of project activities of the municipal administration.

Keywords: project management, local government, project activities

\section{Streszczenie}

W artykule omówiono wpływ realizacji projektów w jednostkach samorządu terytorialnego na skuteczność w rozwoju miasta zgodnie z zaplanowanymi celami strategicznymi. Rozważania dotyczą również wpływu doświadczeń samorządów w Polsce na zarządzanie projektami w jednostkach samorządowych na Ukrainie. W pracy przedstawiono opinie mieszkańców miasta Łuck na Ukrainie na temat oceny skuteczności działalności projektowej administracji samorządowej.

Słowa kluczowe: zarządzanie projektami, jednostki samorządu terytorialnego, działalność projektowa

\section{Wstęp}

Główną funkcją działalności projektowej jest osiągnięcie wytyczonych przez organizację celów. Ich realizacja we współczesnym, dynamicznym świecie coraz częściej jest kojarzona z celami rozwojowymi i przy realizacji projektów. 
Jeśli wcześniej działalność projektowa kojarzyła się tylko z biznesem, to dzisiaj praca związana $\mathrm{z}$ realizacją projektów wykonywana jest także $\mathrm{w}$ instytucjach publicznych. W artykule została przedstawiona działalność projektowa jednostki samorządu terytorialnego miasta Łuck na Ukrainie, w tym powiązanie z celami strategicznymi rozwoju miasta. Warto podkreślić, że przy realizacji projektów na Ukrainie, w obszarze działalności projektowej, władza samorządu korzystała z doświadczenia polskich organizacji publicznych. Ważne jest jednak, żeby korzystając z polskich doświadczeń, nie popełniać jednocześnie błędów. Kilka lat temu Grażyna Prawelska-Skrzypek i Beata Jałocha pisały, że wiele jednostek samorządu terytorialnego realizuje określone projekty dlatego, że akurat na takie projekty mogą pozyskać środki albo naśladują one udane przedsięwzięcia jednostek innych. Po zakończeniu projektów często aktywność, którą one inicjowały, jest zarzucana, a organizacje szukają innych środków na nowe projekty [Prawelska-Skrzypek, Jałocha, 2014: 9]. Polskie jednostki samorządu terytorialnego dopiero obecnie zaczynają rozumieć, że taka droga nie prowadzi do ich rozwoju. Po zrealizowaniu tysięcy projektów polskie jednostki samorządu terytorialnego zaczynają doceniać strategiczne podejście do działalności projektowej, znaczenie dobrego skomponowania portfela projektów oraz zarządzania nim, podporządkowanego realizacji strategicznych celów organizacji [Prawelska-Skrzypek, 2011: 11]. Ukraina dopiero wkracza w fazę projektyzacji jednostek samorządu terytorialnego. Powinna skorzystać z doświadczeń Polski, i od początku rozwijać działalność projektową z myślą o realizacji celów strategicznych oraz najlepszego wykorzystania zasobów. To pozwoli szybciej i lepiej osiągnąć cele rozwojowe.

Jednostki samorządu terytorialnego zaczęły rozwijać działalność projektową niemal od początku przemian ustrojowych w Polsce. Niektóre projekty były realizowane przez organizacje pozarządowe i obejmowały całą Polskę. Z powodzeniem przeprowadzono takie projekty, jak „Przejrzysta Polska” oraz „Przyjazna administracja”. Koncentrowały się one przede wszystkim na wypracowaniu i wdrażaniu w organizacjach publicznych procedur administracyjnych na podstawie jasnych zasad i etycznych kryteriów zachowania urzędników oraz na zapewnieniu wysokiej jakości usług administracyjnych dla obywateli. Przynosiły także poprawę mechanizmów angażowania społeczeństwa w podejmowanie decyzji odnośnie do rozwoju miejscowości [Kawałko, 2015: 3]. Dzięki uwzględnianiu opinii obywateli takie projekty przyczyniły się do podniesienia jakości pracy administracyjnej. Na Ukrainie są prowadzone pewne działania w tym kierunku, ale przede wszystkim skupiają się one na poziomie projektów lokalnych i nie są regularne.

Celem pracy jest sprawdzenie, czy projekty realizowane w Łucku na Ukrainie odpowiadają celom strategicznym tej jednostki samorządowej, czy oddziałują one na rozwój miasta i wpływają na polepszenie świadczonych usług administracyjnych.

Niniejsze opracowanie zostało przygotowane za pomocą następujących metod badawczych: analizy i syntezy literatury przedmiotu, analizy tekstów dokumentów, metody obserwacji oraz badań ankietowych opinii mieszkańców 
miasta Łuck na Ukrainie. Przeprowadzone badania rzuciły światło na problemy zarządzania działalnością projektową w jednostkach samorządu terytorialnego na Ukrainie.

\section{Działalność projektowa w samorządach terytorialnych}

Aby zarządzanie działalnością projektową miało pozytywne skutki, trzeba mobilizować istniejące zasoby dla realizacji projektów, które są najważniejsze dla jednostki terytorialnej. Skuteczność działalności projektowej opiera się na minimalizacji ryzyka. Często ryzyko jest powiązane z niestabilnością podstaw prawnych, reguł realizacji inwestycji, sytuacji makroekonomicznej w państwie, stabilności politycznej. Dlatego zarządzanie ryzykiem jest jednym z ważnych czynników przy planowaniu oraz realizacji projektów [Minajewa, 2011: 3]. Istotnym zasobem w momencie planowania projektu jest źródło finansowania. Nie zawsze chęci administracji dotyczące rozwoju miasta oraz zmiany $\mathrm{w}$ gospodarce regionu pokrywają się $\mathrm{z}$ ukierunkowanymi na to środkami finansowymi. Jednostki samorządu terytorialnego muszą więc dostosowywać się do pewnych zasad oraz wymogów programów udostępniających środki na realizację projektów.

W latach 2007-2013 powstały pierwsze programy europejskiej współpracy terytorialnej, które były współfinansowane ze środków Europejskiego Funduszu Rozwoju Regionalnego. Taka współpraca stała się jednym z trzech celów polityki spójności'. W Strategicznych Wytycznych Wspólnotowych na ten okres dotyczących spójności wskazano także terytorialny wymiar polityki spójności, gdzie zdefiniowano trzy priorytety interwencji, czyli:

- wkład miast w rozwój gospodarczy i tworzenie miejsc pracy;

- wspieranie dywersyfikacji działalności gospodarczej na obszarach wiejskich;

- współpracę przygraniczną, ponadnarodową i międzyregionalnąa ${ }^{2}$.

W latach 2007-2013 europejska współpraca terytorialna była współfinansowana ze środków Europejskiego Funduszu Rozwoju Regionalnego ${ }^{3}$, w ramach której przyjęto 3 podstawowe obszary wsparcia UE: przygraniczny, transnarodowy oraz międzyregionalny. W obszarze przygranicznym, jak zauważa Bogdan

${ }^{1}$ Rozporządzenie Rady (WE) nr 1083/2006 z dnia 11 lipca 2006 r. ustanawiające przepisy ogólne dotyczące Europejskiego Funduszu Rozwoju Regionalnego, Europejskiego Funduszu Społecznego oraz Funduszu Spójności i uchylające Rozporządzenie (WE) nr 1260/1999, Dz. Urz. UE, L 210/25, 31.07.2006.

2 Polityka spójności wspierająca wzrost gospodarczy i zatrudnienie: strategiczne wytyczne Wspólnoty na lata 2007-2013. Decyzja Rady nr 2006/702/WE z dnia 6 października 2006 r. w sprawie strategicznych wytycznych Wspólnoty dla spójności. Dz. Urz. UE, L 291, 21.10.2006.

${ }^{3}$ Rozporządzenie (WE) nr 1080/2006 Parlamentu Europejskiego i Rady z dnia 5 lipca 2006 r. w sprawie Europejskiego Funduszu Rozwoju Regionalnego i uchylające Rozporządzenie (WE) nr 1783/1999, Dz. Urz. UE, L 210, 31.07.2006, s. 1. 
Kawałko, wskazano na transgraniczny rozwój w wymiarze gospodarczym, społecznym i środowiskowym. Głównymi beneficjentami i uczestnikami wdrażania projektów programu Polska-Białoruś-Ukraina 2007-2013 były instytucje centralne, samorządowe, podmioty gospodarcze, organizacje pozarządowe. W założeniach programu udział partnerów z Ukrainy i z Białorusi ukierunkowany był na wykorzystanie dorobku i doświadczeń europejskich, a także wyników i dobrych praktyk strony polskiej, w tym z wcześniejszej współpracy w ramach programów realizowanych na zachodniej granicy Polski. W trakcie realizacji programu ogłoszono i przeprowadzono 3 nabory wniosków, w 2009, 2011 oraz 2012 roku [Kawałko, 2015: 3].

Partnerami lokalnych władz publicznych na Ukrainie są agencje rządowe innych krajów (takich jak Agencja Rozwoju Międzynarodowego [USAID], kanadyjska agencja rozwoju międzynarodowego [CIDA], Szwedzka Agencja działająca w sferze międzynarodowej współpracy oraz rozwoju [SIDA] oraz inne, międzynarodowe organizacje [gospodarcze, finansowe, humanitarne i in.]), międzynarodowe korporacje, przedsiębiorstwa $\mathrm{z}$ innych krajów i międzynarodowe organizacje pozarządowe.

Główne formy współpracy międzynarodowej władz lokalnych na Ukrainie są opracowywane i później realizowane bezpośrednio przez komitety wykonawcze rad lokalnych, gminnych, powiatowych i regionalnych administracji. Organizacyjnoprawne formy takiej współpracy mają zróżnicowany oraz wieloaspektowy charakter. Taka współpraca rodzi całokształt stosunków międzynarodowych na szczeblu lokalnym i regionalnym.

\section{Strategiczne cele samorządu a projektyzacja}

Władze lokalne na Ukrainie nie wykorzystują w odpowiednim stopniu dostępnych narzędzi usprawniających zarządzanie miastem. Zdaniem Magdaleny Dołhasz i współautorów w zarządzaniu strategicznym głównym zagadnieniem jest stworzenie mechanizmu wdrożeniowego. W przypadku przygotowania tylko dokumentów strategia przyjmuje jedynie charakter komunikacyjny [Dołhasz i in., 2009: 3]. Dla jednostek samorządu terytorialnego strategia stanowi scenariusz przyszłości, do którego dążą władze samorządowe. Jest on oparty na analizie sytuacji bieżącej i określających go czynników oraz na wyborze pożądanych kierunków rozwoju. Marek Ziółkowski podkreśla, że zasadą strategii rozwoju jednostek samorządu terytorialnego jest kompromis pomiędzy głównymi siłami jednostki terytorialnej (samorządem, przedsiębiorcami, organizacjami społecznymi) co do oczekiwanych kierunków rozwoju oraz podziału odpowiedzialności i kompetencji [Ziółkowski, 2015: 4]. Strategiczne zarządzanie jest ważne dla jednostek samorządu terytorialnego, zwłaszcza że jednostki samorządowe z założenia muszą przestrzegać strategii rozwoju miasta lub regionu. Przy realizacji pojedynczych projektów administracja musi być zatem odpowiedzialna, żeby nie zniechęcić obywateli oraz dążyć do poprawy sprawności i efektywności 
działania administracji lokalnej. Realizacja poszczególnych projektów ma przede wszystkim służyć osiąganiu celów rozwojowych, które spowodują podniesienie jakości życia czy wzrost konkurencyjności gospodarki regionalnej [Prawelska-Skrzypek, 2011: 10]. Według proponowanego podejścia w większości strategii zdefiniowane cele stanowią podstawę do tworzenia projektów. O ile cele mają charakter trwały, o tyle swoboda doboru projektów jest, zdaniem Adama Niedzielskiego, narzędziem sprawowania władzy politycznej. Rozwiązanie takie prowadzi do stabilności prowadzonej polityki przy jednoczesnym zachowaniu elastyczności doboru środków dla realizacji projektów, tak aby nie ograniczać swobody wyboru politycznego [Niedzielski, 2015: 3].

We współczesnej metodyce zarządzania rozwojem organizacji zaleca się stosowanie koncepcji zarządzania strategicznego, które powinno być silnie powiązane $\mathrm{z}$ działaniami marketingowymi. Zarządzanie strategiczne jest działaniem przemyślanym, perspektywicznie zaplanowanym, skutecznie zorganizowanym i efektywnie realizowanym. Realizacja jakiegokolwiek działania musi być stale kontrolowanym procesem. Wdrażanie strategii rozwoju organizacji skupia uwagę zarządzających organizacją na jak najlepszym wykorzystaniu własnych walorów i zasobów w długookresowej perspektywie [Ziółkowski, 2015: 2]. Istotą jest podejmowanie czynności i działań, dzięki którym organizacja może projektować swoją przyszłość tak, by nie decydowały o niej przypadkowe wydarzenia.

\section{Projekty realizowane w jednostce samorządu terytorialnego w Łucku na Ukrainie}

Łuck położony jest w malowniczej części zachodniej Ukrainy. To jedno z najstarszych miast ukraińskich. Obecnie Łuck liczy 220 tys. mieszkańców. Rozwija się tu przemysł samochodowy, elektrotechniczny, spożywczy i lekki. Życie intelektualne skupia się wokół Uniwersytetu Wołyńskiego oraz licznych instytutów naukowych. Łuck jest członkiem Związku Miast Ukraińskich. Realizacja projektów w samorządzie miasta Łuck przebiega we współpracy z różnymi organizacjami. Partnerami jednostki samorządu terytorialnego są organizacje pozarządowe, samorządy z Ukrainy i z Polski. W niniejszym artykule, w celu zilustrowania rozwoju współpracy projektowej, odniesiono się do przykładu dwóch miast: Lublina (Polska) i Łucka (Ukraina), które w 1996 roku podpisały umowę partnerstwa.

Współpraca pomiędzy Łuckiem i Lublinem przebiega na wielu płaszczyznach. Według opinii kierownika referatu ds. projektów międzynarodowych miasta Lublin: „Inicjatorem większości projektów była strona polska, ale zawsze w uzgodnieniu potrzeb partnera. W trakcie realizacji projektów transgranicznych 2007-2013 i obecnie przygotowywanych 2014-2020 coraz częściej inicjatorem projektów jest strona ukraińska".

W ramach działań finansowanych z funduszy zewnętrznych w latach 20042008 zrealizowano 12 wspólnych projektów. 
W pierwszym etapie przy udziale dwóch organizacji z Lublina (fundacji „Centrum miejskiego rozwoju” oraz fundacji „Młoda demokracja”), ukraińskie organizacje w składzie: Centrum Publicznych Organizacji Młodzieżowych Wołyni „Nasza sprawa” oraz Regionalna Organizacja Inicjatywy Młodzieży na Wołyni „Alternatywa” z Łucka, w ciągu sześciu miesięcy, od lipca do grudnia 2007 roku, zrealizowały w urzędzie miasta Łuck projekt „Strategia-partnerstwo-inicjatywa. Praktyczne doświadczenie Polski w sferze planowania strategicznego oraz rozwoju lokalnego". Celem tego projektu było wsparcie samorządu Łucka poprzez przekazywanie wiedzy i doświadczenia w zakresie reform administracji samorządowej w Polsce oraz omówienie konsekwencji integracji europejskiej dla samorządu w Polsce. Ważnym celem tego projektu była również nauka planowania strategicznego oraz zarządzania w instytucjach publicznych.

Następnym krokiem było wzmocnienie współczesnej administracji na Ukrainie - w ciągu dwóch miesięcy (wrzesień-październik 2009 r.) prowadzony był projekt „Profesjonalna administracja oraz działająca instytucja - seminaria i spotkania dla przedstawicieli władz ukraińskich". Na podstawie własnych doświadczeń samorządu Lublina pokazano możliwe działania w różnych sferach pracy administracji. Zorganizowano również szkolenia na tematy dotyczące zarządzania w administracji samorządowej, ochrony środowiska i zrównoważonego rozwoju, informatyzacji w administracji, współpracy międzynarodowej, pozyskiwania dodatkowych środków oraz projektów transgranicznych.

$\mathrm{Z}$ informacji, jaka została zamieszczona na stronie internetowej samorządu Łucka, wynika, że w 2010 roku, od marca do grudnia, podjęto kolejny raz współpracę $\mathrm{z}$ Lublinem $\mathrm{w}$ ramach realizacji wspólnego projektu doskonalenia pracy w administracji publicznej „Miasta rozwoju - wykorzystanie polskich oraz ukraińskich doświadczeń w tworzeniu nowoczesnego samorządu”. Projekt został sfinansowany przez Ministerstwo Spraw Zagranicznych RP w ramach programu „Polska pomoc". Podczas trwania projektu przeprowadzono analizę technik zarządzania wykorzystywanych w samorządach ukraińskich w różnych sferach. Pod uwagę wzięto: system zarządzania jakością, planowanie i organizację rozwoju miasta, strategie marketingowe, procedury badania poziomu satysfakcji obywateli oraz działania mające na celu poprawę usług dla mieszkańców. W tym projekcie uczestniczyło kilka miast ukraińskich: Łuck, Lwów, Równe, Tarnopol, Iwano-Frankiwsk, Dniepropietrowsk, Ługańsk, Sumy.

Większość realizowanych projektów była związana z rozwojem turystycznym, wymianą kulturową oraz nawiązaniem kontaktów transgranicznych. Jeśli chodzi o wspieranie rozwoju miasta $\mathrm{w}$ innych aspektach, to finansowane były pojedyncze projekty, np. z USAID (United States Agency for International Development) „Reforma ogrzewania miejskiego”. W ramach tego projektu w ciągu trzech lat od 2009 do 2011 roku została wprowadzona pomoc dla administracji samorządowej w stworzeniu trwałego i stabilnego finansowo sektora dostawy ciepła, w zapewnieniu świadczenia usług publicznych wysokiej jakości.

Większość inicjatyw projektowych jest wynikiem podpisanego w 2007 dokumentu „Strategia współpracy transgranicznej Lublin-Łuck-Lwów-Iwano-Frankiwsk" i określonych w nim istotnych obszarów działań ciekawych dla obu stron. 
Jak mówi kierownik referatu ds. projektów międzynarodowych miasta Lublin: „Decyzja o wspólnej realizacji obecnego projektu została podjęta w trakcie opracowania dokumentu »Strategia współpracy transgranicznej Lublin-Luck-LwówIwano-Frankiwsk«. Podpisywanie takiego dokumentu jest istotnym wydarzeniem wzmacniającym współpracę projektową. Wypracowane wieloletnie kontakty owocują dobrą współpracą. Jednymi z obszarów działań wyznaczonych w »Strategii« są dobre rządzenie i partycypacja społeczna".

Samorządowa współpraca sąsiadujących miast dotyczy wielu płaszczyzn, od wymiany doświadczeń pomiędzy wydziałami urzędów do wspólnej promocji i wspierania przedsiębiorczości. Dobra współpraca na szczeblu władz miejskich oraz działania wspierające transgraniczną współpracę gospodarczą umożliwiają lubelskim firmom rozwój swojego profilu działalności na rynku ukraińskim. Realizowanie projektów przez polskie oraz ukraińskie samorządy wpłynęło pozytywnie na rozwój współpracy transgranicznej w takich dziedzinach, jak: turystyka, ochrona środowiska, wymiana kulturalna, rozwój przedsiębiorczości.

\section{Zgodność projektów z celami strategicznymi}

Cele strategiczne rozwoju miasta zawsze zawierają w sobie działania polepszające jakość życia mieszkańców, m.in. te, które są skierowane na zwiększenie jakości świadczonych usług $\mathrm{w}$ jednostce samorządu terytorialnego. W dokumentach samorządu Łucka nie ma wprost opisanej strategii rozwoju. Trzeba domniemywać, że cele strategiczne są oraz wiążą się z podniesieniem poziomu jakości życia mieszkańców. Z tego wynika, że projekty, które zostały zrealizowane, korespondują z celami strategicznymi rozwoju miasta w Łucku.

Przykładem są zrealizowane dwa projekty, które przyczyniają się do rozwoju miasta oraz do podniesienia poziomu jakości świadczonych usług $\mathrm{w}$ urzędzie samorządowym (za: oficjalna strona internetowa administracji samorządowej w Łucku, http://www.lutskrada.gov.ua/perelik-proektiv-realizovanyh-vykonavchym-komitetom-luckoyi-miskoyi-rady-protyagom-2006-2010-rokiv [dostęp: 15.09.2016]):

I. Poprawa świadczenia usług administracyjnych dla mieszkańców regionów transgranicznych poprzez tworzenie sieci centrów świadczenia usług administracyjnych i rozwoju współpracy między Centrum Świadczenia Usług Administracyjnych (CŚUA) w Łucku, Centrum Świadczenia Usług Administracyjnych (CŚUA) w Iwano-Frankiwsku oraz Biurem Obsługi Mieszkańców (BOM) w Lublinie.

Cel projektu:

Podniesienie jakości świadczenia usług administracyjnych dla mieszkańców regionów transgranicznych poprzez tworzenie sieci centrów świadczenia usług administracyjnych i rozwoju współpracy między ośrodkami wymienionymi w temacie projektu. 
Partnerzy projektu:

- Partner Wiodący - Komitet Wykonawczy Rady Miasta Łuck

- Partner 1 - Organizacja pozarządowa Fundacja Rozwoju Lokalnego

- Partner 2 - Gmina Lublin

- Partner 3 - Komitet Wykonawczy Rady Miasta Iwano-Frankiwsk

Termin realizacji: 1 marca 2010 - 31 grudnia 2010

Działania projektu:

- Monitoring obecnego stanu CŚUA na Ukrainie oraz BOM w Lublinie.

- Analiza normatywnoprawnej bazy dokumentów dotyczących działalności CŚUA oraz BOM.

- Prowadzenie wizyt studyjnych w celu zapoznania się z doświadczeniami funkcjonowania CŚUA w Łucku, CŚUA w Iwano-Frankiwsku oraz BOM w Lublinie.

- Stworzenie oraz funkcjonowanie Grupy Monitoringowej zajmującej się działalnością partnerską CŚUA oraz BOM.

- Przeprowadzenie konferencji z wizytą studyjną dla przedstawicieli partnerskich samorządów Wołynia, Lwowszczyzny, Iwano-Frankiwszczyzny oraz Lubelszczyzny.

- Stworzenie uniwersalnych „kejsów” dla powstania i funkcjonowania CŚUA i BOM oraz rozpowszechnienie ich wśród zainteresowanych organów władzy samorządowej innych miast regionu transgranicznego Ukrainy oraz Polski.

- Podwyższenie kwalifikacji pracowników CŚUA oraz BOM.

- Funkcjonowanie przejrzystego systemu elektronicznego przepływu dokumentów.

- Udoskonalenie infrastruktury CŚUA oraz BOM.

- Przeprowadzenie kampanii promocyjnej, dotyczącej CŚUA oraz BOM.

- Przeprowadzenie niezależnej oceny poziomu zadowolenia mieszkańców i pracowników CŚUA oraz BOM.

- Opracowanie zunifikowanych usług administracyjnych oraz wprowadzenie ich w każdym CŚUA oraz BOM w celu realizacji usług administracyjnych dla cudzoziemców.

- Otwarcie punktów informacyjnych w CŚUA oraz BOM dla obsługi cudzoziemców.

II. Rozwój usług komunalnych, w ramach zrównoważonego rozwoju obszarów miejskich na granicy polsko-ukraińskiej (za: oficjalna strona internetowa administracji samorządowej w Łucku, http://www.lutskrada.gov. ua/perelik-proektiv-realizovanyh-vykonavchym-komitetom-luckoyi-miskoyi-rady-protyagom-2006-2010-rokiv [dostęp: 15.09.2016]):

Cel projektu:

Pobudzenie dynamiki rozwoju oraz poprawy jakości świadczonych usług komunalnych w miastach gminy Łublina i Wołyniu poprzez transfer wiedzy i wymiany doświadczeń. 
Partnerzy projektu:

- Partner Wiodący - Stowarzyszenie lokalnych władz Euroregionu Bug

- Partner 1 - Gmina Hill City Komitetu Wykonawczego w radzie miejskiej

- Partner 2 - Komitet Wykonawczy Rady Miasta Łuck

Termin realizacji: 1 listopada 2014 - 31 października 2015

Działania projektu:

- Przygotowanie broszury „Komunalne organizacje miasta Łuck”.

- Przeprowadzanie licznych wizyt studyjnych dla pracowników miejskich przedsiębiorstw komunalnych, spotkania polsko-ukraińskiej grupy ekspertów na wypracowanie wniosków eksperckich narzędzi.

- Dokonanie remontu w budynku, który został przydzielony Centrum Transgranicznej Współpracy Gospodarczej w Łucku.

- Wykonanie dokumentacji budowlanej i geologicznej inwentaryzacji terenów zalewowych.

- Otworzenie Centrum Transgranicznej Współpracy Gospodarczej w Łucku.

Poniżej przedstawiono wyniki przeprowadzonego badania, w którym zajęto się opinią mieszkańców Łucka o działalności projektowej samorządu miejskiego. Narzędziem badań była ankieta, dotycząca działalności projektowej samorządu miasta Łuck. W ankiecie zostały wymienione dwa przedstawione już projekty, które zostały zrealizowane przez samorząd. W wyniku ich realizacji powstały centrum usług administracyjnych oraz katalog organizacji komunalnych.

Badanie zostało przeprowadzone na przełomie lipca i sierpnia 2016 roku za pośrednictwem internetu. W badaniu wzięło udział 50 osób: 27 kobiet i 23 mężczyzn. Ankietowane osoby reprezentowały różne grupy wiekowe: od 20 do 45 lat oraz od 46 do 70 lat.

Na potrzeby artykułu sformułowano następujące pytania badawcze:

- Czy Pan/Pani interesuje się działalnością samorządu Łucka?

- Czy zna Pan/Pani temat działalności projektowej samorządu Łucka?

- Czy słyszał/a Pan/Pani o realizacji projektów pod nazwami:

1) Rozwój usług komunalnych w ramach zrównoważonego rozwoju obszarów miejskich na granicy polsko-ukraińskiej; oraz

2) Poprawa świadczenia usług administracyjnych dla mieszkańców regionów transgranicznych poprzez tworzenie sieci centrów świadczenia usług administracyjnych i rozwoju współpracy między Centrum Świadczenia Usług Administracyjnych w Łucku, Centrum Świadczenia Usług Administracyjnych w Iwano-Frankiwsku oraz Biurem Obsługi Mieszkańców w Lublinie.

- Czy uważa Pan/Pani, że po realizacji tych projektów jakość świadczonych usług administracyjnych oraz komunalnych została poprawiona?

- Czy Pana/Pani zdaniem po realizacji tych projektów działalność administracji stała się bardziej otwarta oraz przejrzysta? 
Warto zauważyć, że wiedzę na temat działalności projektowej wykazało $50 \%$ badanych; na temat realizacji projektu doskonalenia usług komunalnych było to $16 \%$ badanych, a $50 \%$ badanych - na temat realizacji projektu skierowanego na poprawę świadczenia usług administracyjnych.

Wyniki odpowiedzi na pytanie na temat poprawy jakości świadczonych usług administracyjnych oraz komunalnych wyglądają następująco: na poprawę jakości usług administracyjnych wskazało $66 \%$ badanych, a na poprawę jakości usług komunalnych $-0 \%$ badanych, czyli nie zauważono jakichkolwiek zmian w jakości świadczonych usług komunalnych.

Ankieta zawierała także trzy pytania otwarte, w których zostały wymienione problemy według opinii mieszkańców związane ze świadczeniem usług administracyjnych. W dwóch pytaniach zostały wymienione propozycje związane $\mathrm{z}$ doskonaleniem usług administracyjnych oraz komunalnych. W tabelach 1,2 i 3 przedstawiono zbiorcze zestawienie opinii mieszkańców na temat problemów oraz propozycji udoskonalenia usług administracyjnych i komunalnych wraz z udziałem procentowym.

Tabela 1

Problemy związane ze świadczeniem usług administracyjnych

\begin{tabular}{|c|l|c|c|}
\hline Lp. & \multicolumn{1}{|c|}{ Wyszczególnienie } & $\begin{array}{c}\text { Liczba } \\
\text { osób }\end{array}$ & $\begin{array}{c}\text { Udział w ogólnej } \\
\text { liczbie } \\
\text { ankietowanych } \\
\text { [w \%] }\end{array}$ \\
\hline 1 & $\begin{array}{l}\text { Godziny pracy oraz lokalizacja centrum świadczenia } \\
\text { usług administracyjnych nie są wygodne. }\end{array}$ & 5 & 10 \\
\hline 2 & $\begin{array}{l}\text { Są duże kolejki w centrum świadczenia usług admini- } \\
\text { stracyjnych. }\end{array}$ & 15 & 30 \\
\hline 3 & $\begin{array}{l}\text { Brak formularzy wniosków, wzorów do wypełnienia, } \\
\text { oraz brak konsultacji ws. usług administracyjnych. }\end{array}$ & 10 & 20 \\
\hline 4 & $\begin{array}{l}\text { Terminy wykonania usług administracyjnych nie są } \\
\text { przestrzegane. }\end{array}$ & 15 & 30 \\
\hline 5 & Nie mam zdania. & 5 & 10 \\
\hline Ogółem ankietowanych & 50 & 100 \\
\hline
\end{tabular}

Źródło: badanie własne

Analiza tabeli 1 wskazuje, że głównymi problemami związanymi ze świadczeniem usług administracyjnych są: istnienie dużych kolejek w centrum świadczenia usług oraz nieprzestrzeganie terminów wykonania usług administracyjnych. Te problemy zostały wskazane przez $60 \%$ badanych (30\%: duże kolejki; $30 \%$ : nieprzestrzeganie terminów wykonania usług). Problem z nieprzestrzeganiem terminów świadczy o braku kompetencji pracowników, i tu pojawia się kolejna kwestia do poprawy zarządzania personelem w samorządzie miasta Łuck. 
Tabela 2

Propozycje związane ze świadczeniem usług administracyjnych

\begin{tabular}{|c|l|c|c|}
\hline Lp. & \multicolumn{1}{|c|}{ Wyszczególnienie } & Liczba osób & $\begin{array}{c}\text { Udział w ogólnej } \\
\text { liczbie ankietowanych } \\
\text { [w \%] }\end{array}$ \\
\hline 1 & $\begin{array}{l}\text { Podnieść jakość usług administracyjnych, w tym } \\
\text { udoskonalić kompetencje pracowników. }\end{array}$ & 20 & 40 \\
\hline 2 & $\begin{array}{l}\text { Otworzyć jeszcze kilka centrów świadczenia usług } \\
\text { administracyjnych. }\end{array}$ & 15 & 30 \\
\hline 3 & $\begin{array}{l}\text { Zmniejszyć kolejki w centrum świadczenia usług } \\
\text { administracyjnych, które są sztucznie wymyślone, } \\
\text { oraz zwiększyć wydajność pracowników. }\end{array}$ & 10 & 20 \\
\hline 4 & Nie mam zdania. & 5 & 10 \\
\hline Ogółem ankietowanych & 50 & 100 \\
\hline
\end{tabular}

Źródło: badanie własne

Tabela 3

Propozycje związane ze świadczeniem usług komunalnych

\begin{tabular}{|c|l|c|c|}
\hline Lp. & \multicolumn{1}{|c|}{ Wyszczególnienie } & $\begin{array}{c}\text { Liczba } \\
\text { osób }\end{array}$ & $\begin{array}{c}\text { Udział w ogólnej } \\
\text { liczbie ankietowanych } \\
\text { [w \%] }\end{array}$ \\
\hline 1 & Zorganizować centrum koordynacji usług komunalnych. & 5 & 10 \\
\hline 2 & Zorganizować jednostki zarządzające budynkiem. & 5 & 10 \\
\hline 3 & Zmniejszyć opłaty za media oraz czynsz. & 20 & 40 \\
\hline 4 & $\begin{array}{l}\text { Zobowiązać poprzednich zarządców do przeprowadze- } \\
\text { nia w budynkach remontu rur. }\end{array}$ & 16 & 32 \\
\hline 5 & Nie mam zdania. & 4 & 8 \\
\hline Ogółem ankietowanych & 50 & 100 \\
\hline
\end{tabular}

Źródło: badanie własne

Analizując propozycje mieszkańców, warto zaznaczyć, że w celu zmniejszenia kolejki w centrum usług administracyjnych oraz przestrzegania terminów wykonywania świadczeń trzeba udoskonalić kompetencje pracowników oraz otworzyć jeszcze kilka centrów świadczenia usług administracyjnych.

W kwestii propozycji mieszkańców dotyczących poprawy świadczenia usług komunalnych warto zauważyć, że nie znajdują one odzwierciedlenia w rzeczywistości. Opłaty za media i czynsz nie są zmniejszane, wręcz przeciwnie: są stale zwiększane. Nie ma możliwości pociągnięcia do odpowiedzialności poprzednich zarządców, a także brak środków, które mogłyby zostać użyte na remont budynków.

Z przeprowadzonego badania wynika, że nie ma spójności pomiędzy władzą samorządu oraz mieszkańcami miasta Łuck. Brak też dostatecznie dobrej 
współpracy, która umożliwiłaby kierownikom samorządu terytorialnego efektywniejsze wykonywanie działań projektowych oraz wybranie potrzebnego do rozwoju miasta kierunku.

\section{Podsumowanie}

Na podstawie analizy przeprowadzonych badań można wysnuć szereg różnych wniosków odnośnie do przemiany miasta Łuck w kontekście współpracy z Lublinem. Rozważyć tutaj należy m.in. następujące zagadnienia:

- działalność projektowa na Ukrainie z pewnością przyczynia się do modernizacji oraz unowocześnienia miejskiej organizacji;

- strategie lokalne powinny być narzędziem rozwoju i porządkowania obszaru, muszą mieć jasno określone instrumenty wdrażania, muszą być z sobą powiązane, ale także muszą współistnieć z celami działania poszczególnych jednostek terytorialnych;

- sposób przygotowania strategii przez samorządy powinien uwzględniać kierunki rozwoju i związane z nimi środki działania (w postaci rozwoju infrastruktury, zachęt, instrumentów polityki, gwarancji itp.), możliwe do wykorzystywania przez mieszkańców w procesie zagospodarowania posiadanych zasobów oraz zasobów możliwych do uzyskania.

Warto także zauważyć, że realizowane projekty odpowiadają domniemanym celom strategicznym jednostki samorządowej w Łucku na Ukrainie. Odnotowano, że mieszkańcy zauważyli poprawę w jakości świadczonych usług administracyjnych. Zmiany w strukturze samorządu prowadzone są powoli. Systemy usług komunalnych oraz organizacji zarządzających budynkami nie są doskonałe i występują tu pewne problemy uniemożliwiające polepszenie działań. Celem realizacji projektów była poprawa jakości usług administracyjnych oraz komunalnych, więc opinie mieszkańców miasta Łuck zawierały dużo słów krytyki na ten temat. $\mathrm{Z}$ tego wynika, że warto realizować lokalne projekty, których rezultatem byłaby poprawa poziomu życia mieszkańców.

Rozwój działalności projektowej Polski zdecydowanie pomaga Ukrainie, która wykorzystuje doświadczenia projektowe w skutecznym opanowaniu metod zarządzania projektami oraz podnoszeniu kompetencji pracowników w tym zakresie. Problemem pozostaje kwestia stopnia spełnienia oczekiwań obywateli poprzez realizację projektów oraz prawidłowy dobór ich zakresu. Skuteczność działalności samorządu powinna być oceniana poprzez poziom zadowolenia mieszkańców. Obecnie na Ukrainie realizacja projektów odbywa się głównie w celu „osiągania wskaźników” oraz otrzymania środków zewnętrznych. Przeprowadzone badania ankietowe wyraźnie wskazują zapotrzebowanie na kompetentnych pracowników w jednostkach samorządowych w Łucku na Ukrainie. $\mathrm{W}$ administracji samorządowej w Łucku realizowane są działania, które poprawiają jakość i efektywność świadczonych usług administracyjnych, ale nadal są aspekty, które wymagają wytężonej pracy. 


\section{Bibiliografia}

Cikarenko I. (2009), Podejście do zarządzania portfelem projektów: adaptacja do sfery municypalnego menedżmentu, http://www. nbuv. gov. ua/e-journals/Patp/2009-01/C hikarenko I Stat. pdf [dostęp: 15.09.2016].

Decyzja Rady nr 2006/702/WE z dnia 6 października 2006 r. w sprawie strategicznych wytycznych Wspólnoty dla spójności. Dz. Urz. UE, L 291, 21.10.2006.

Dołhasz M., Fudaliński J., Kosala M., Smutek H. (2009), Podstawy zarzadzania. Koncepcjestrategie - zastosowania, PWN, Warszawa.

Izdebski H., Kulesza M. (2004), Administracja publiczna. Zagadnienia ogólne, Liber, Warszawa.

Kawałko B. (2015), Program Polska-Białoruś-Ukraina w polityce rozwoju regionów przygranicznych, „Barometr Regionalny. Analizy i Prognozy”, 1(13), 7-27.

Kożuch B. (2007), Nauka o organizacji, CeDeWu Wydawnictwa Fachowe, Warszawa.

Minajewa G. (2011), Zarządzanie działalnościa projektowa jednostkami samorzadu terytorialnego dla umocnienia infrastruktury terytorium, „Teoria i Praktyka Zarządzania Publicznego", 3, 373-379.

Niedzielski A. (2015), Rola kontroli zarzadczej w realizacji Strategii Modernizacji Przestrzeni Sprawiedliwości w Polsce na lata 2014-2010, Zeszyty Naukowe Uniwersytetu Szczecińskiego, 864, „Finanse, Rynki Finansowe, Ubezpieczenia”, 76(2), 387-399.

Prawelska-Skrzypek G. (2006), Zarzadzanie projektami jako nowoczesny instrument zarzadzania publicznego [w:] eadem (red.), Zarzadzanie w sektorze publicznym i obywatelskim. Wybrane problemy, Fundacja WZ, ISP UJ, Kraków.

Prawelska-Skrzypek G. (2011), Zarzadzanie projektami jako szansa i wyzwanie dla administracji publicznej, Zeszyty Naukowe Wyższej Szkoły Bankowej we Wrocławiu, 26, 195-206.

Prawelska-Skrzypek G., Jałocha B. (2014), Projektyzacja sektora publicznego w Polsce - Implikacje dla organizacji samorządu terytorialnego, „Zarządzanie Publiczne”, 27, 273-284.

Rozporządzenie Rady (WE) nr 1083/2006 z dnia 11 lipca 2006 r. ustanawiające przepisy ogólne dotyczące Europejskiego Funduszu Rozwoju Regionalnego, Europejskiego Funduszu Społecznego oraz Funduszu Spójności i uchylające Rozporządzenie (WE) nr 1260/1999.

Rozporządzenie (WE) nr 1080/2006 Parlamentu Europejskiego i Rady z dnia 5 lipca 2006 r. w sprawie Europejskiego Funduszu Rozwoju Regionalnego i uchylające Rozporządzenie (WE) nr 1783/1999, Dz. Urz. UE, L 210, 31.07.2006.

Szyjewski Z. (2004), Metodyki zarzadzania projektami, Placet, Warszawa.

Tkacz A. (2015), Uczestnictwo międzynarodowych pomiędzyurzędowych i pozarządowych organizacji w procesie rozwoju międzynarodowej wspótpracy jednostek władzy miejskiej na Ukrainie, Zeszyty Naukowe Czornomorskiego Uniwersytetu im. P. Mogyły, 263(252), 137-143.

Wyrozębski P. (2009), Biuro projektów, Bizarre, Warszawa.

Wysocki R., McGary K. (2005), Efektywne zarządzanie projektami, Onepress, Warszawa. Zarządzanie projektem europejskim (2007), red. M. Trocki, B. Grucza, PWE, Warszawa.

Ziółkowski M. (2015), Strategiczne zarządzanie rozwojem gminy, „Ruch Prawniczy, Ekonomiczny i Socjologiczny", 77(1), 145-163. 